\title{
Synthesis and Characterizations of Strontium Cerium Oxide Phosphor
}

Pradip Z. Zambare ${ }^{1^{*}}$, K. D. Girase ${ }^{1}$ O. H. Mahajan ${ }^{2}$

${ }^{1}$ Department of Physics, S. V. S's Dadasaheb Rawal College, Dondaicha, India.

E-mail pzzambare@rediffmail.com.

${ }^{2}$ Department of Physics, M. J. College Jalgaon (M.S.), India.

\section{ABSTRACT}

E-mail Ohmahajan56@gmail.com.

A new Strontium Cerium Oxide $\left(\mathrm{Sr}_{4} \mathrm{Ce}_{2} \mathrm{O}_{7}\right)$ blue phosphor with, orthorhombic structure was synthesized via standard solid state reaction method using strontium oxide and cerium oxide as a raw materials. The samples were characterized by Thermo analytical techniques (TG, DTA, and DTG), Fourier transformation infrared (FTIR) spectroscopy, Raman spectroscopy, and Photoluminescence studies at room temperature. In excitation spectra two excitation bands were located at 361 and $391 \mathrm{~nm}$ respectively. The emission spectrum was a broad band peaking at $474 \mathrm{~nm}$, which was suitable for the doping of rare earth ions.

\section{Keywords}

TG, DTA, FTIR, Raman spectroscopy, $\mathrm{Sr}_{4} \mathrm{Ce}_{2} \mathrm{O}_{7}, \mathrm{X}$-ray diffraction .

\section{Academic Discipline And Sub-Disciplines}

Physics, Luminescence

\section{SUBJECT CLASSIFICATION}

Spectroscopy, Optical properties

\section{TYPE (METHOD/APPROACH)}

Solid state reaction method

\section{Council for Innovative Research}

\author{
Peer Review Research Publishing System
}

Journal: Journal of Advances in Chemistry

Vol 3, No. 1

editor@cirworld.com

www.cirworld.com, member.cirworld.com 


\section{INTRODUCTION}

The development of new compound for ultraviolet- excited phosphor is of great importance for flat panel display and illumination technology. Compared with organic materials and sulfide phosphors, Oxide- based phosphors have the advantages: stable crystalline structure and physical and chemical stability. Therefore oxide based phosphors, especially rare earth (RE) based oxides, are attracting more and more attention [1-5]. For full colour RE- based phosphors, the red and green emissions are generally generated by the $\mathrm{f}-\mathrm{f}$ transitions of $\mathrm{Eu}^{3+}$ and $\mathrm{Tb}^{3+}$ while the blue one is caused by the $\mathrm{d}-\mathrm{f}$ transitions of $\mathrm{Eu}^{2+}$ or $\mathrm{Ce}^{3+}$. To date, satisfactory red and green phosphors have been commercially available. However, comparable materials for blue emission are still lacking and they are the target of many research works [6-7]. White lightemitting diode(LED), the so- called next generation solid state lighting (SSL), with the advantages of long lifetime, saving energy consumption, and environmental friendly characteristics are attracting more attentions [8]. In view of application, white LEDs are expected to open up a great number of exciting new application field: white light sources to replace traditional incandescent and fluorescent lamps, backlights for portable electronics, medical, and architecture lighting etc [10]. The broad emission band is suitable for the doping of rare earth ions in pursuing new luminescent materials [11]. In this paper, we report here a new composition of blue strontium cerium oxide $\left(\mathrm{Sr}_{4} \mathrm{Ce}_{2} \mathrm{O}_{7}\right)$ was synthesized using solid state reaction method in air atmosphere. To the best of my knowledge, there is no literature is available on thermal analysis, Fourier transform infrared (FTIR), Raman spectra and luminescent properties of the synthesized new strontium Cerium Oxide $\left(\mathrm{Sr}_{4} \mathrm{Ce}_{2} \mathrm{O}_{7}\right)$.

\section{MATERIALS AND METHODS}

The starting materials were; Strontium Carbonate $\mathrm{SrCO}_{3}$, Cerium Oxide $\mathrm{Ce}_{2} \mathrm{O}_{3}$, of $99.5 \%$ purity. The starting materials were taken in Stoichiometric proportions of (4:1) were thoroughly homogenized in agate mortar for 45 min and then transferred to alumina crucibles for heat treatment in air in muffle furnace. The compounds were subjected to heat treatment at $1050-1200{ }^{\circ} \mathrm{C}$ for $40-50$ hours with three intermediate grindings and heating and finally cooled to room temperature by furnace shut off. All samples were prepared by same technique.

Thermo gravimetric analysis (TG, DTG, and DTA) of $\mathrm{Sr}_{2} \mathrm{Ce}_{2} \mathrm{O}_{7}$ blue phosphor was carried out in air atmosphere in 30$1200^{\circ} \mathrm{C}$ temperature range using a Perkin Elmer Diamond TG/DTA instrument. The initial mass of sample taken for recording the TG/DTA curves was $64.778 \mathrm{mg}$ and hold for $1.0 \mathrm{~min}$ at $30^{\circ} \mathrm{C}$, and then heating rate was maintained at $10^{\circ}$ $\mathrm{C} / \mathrm{min}$. The powder X- ray diffractograms (XRDs) of the compounds were recorded using an automated Rigaku Miniflex Xray diffractometer (D Max III VC, Japan). The observed (hkl) reflections and their intensities were compared with the calculated ones generated using the computer program POWD (an Interactive Powder Diffraction Data Interpretation and Indexing Program, Version 2.2). The FTIR spectra of $\mathrm{Sr}_{4} \mathrm{Ce}_{2} \mathrm{O}_{7}$ were recorded on SHIMADZU IRAffinity-1 spectrophotometer with $\mathrm{KBr}$ pellet method over the wave number range $400-4,000 \mathrm{~cm}^{-1}$. The photoluminescence excitation and emission spectra were recorded at room temperature using Spectrofluorophotometer (SHIMADZU, RF 5301 PC) equipped with a $150 \mathrm{~W}$ Xenon lamp as excitation source

\section{RESULT AND DISCUSSIONS}

\subsection{Thermal analysis}

Fig. 1 shows simultaneous TG, and DTA curves of the precursor prepared by solid state reaction method. Initial mass loss of about $0.417 \%$ in TG curve in the range of temperature $116.68{ }^{\circ} \mathrm{C}$ to $265.93{ }^{\circ} \mathrm{C}$ arises due to starting of reaction. The mass loss of about $18.66 \%$ occurs through the broad range $565.43{ }^{\circ} \mathrm{C}$ to $1200{ }^{\circ} \mathrm{C}$ due to the reaction between $\mathrm{SrCO}_{3}$ and $\mathrm{Ce}_{2} \mathrm{O}_{3}$ accompanied by release of $\mathrm{CO}_{2}$ it is in good agreement with the calculated value $18.83 \%$. The step inflection point in this stage occurs at $1061.55{ }^{\circ} \mathrm{C}$ and onset temperature is $965.80{ }^{\circ} \mathrm{C}$. After this stage TG curve did not show an appreciable mass change in the temperature range of $1080-1200^{\circ} \mathrm{C}$, indicate that the precursor is thermally stable in this range.

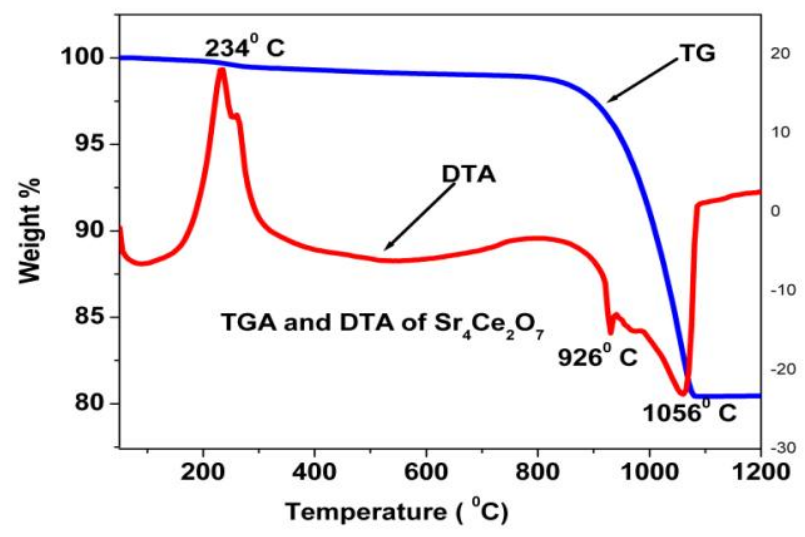

Fig. 1: TG, DTA curve of $\mathrm{Sr}_{4} \mathrm{Ce}_{2} \mathrm{O}_{7}$ 
The endothermic maximum below $100{ }^{\circ} \mathrm{C}$ in DTA curve is due to loss of water absorbed by the samples when handled in air. The exothermic at temperature $233.37{ }^{\circ} \mathrm{C}$ is occurs due to the phase change in starting of reaction between $\mathrm{SrCO}_{3}$ and $\mathrm{Ce}_{2} \mathrm{O}_{3}$. The endothermic at $926{ }^{\circ} \mathrm{C}$ and $1056{ }^{\circ} \mathrm{C}$ in DTA curve corresponds to the mass loss due to the release of $\mathrm{CO}_{2}$.

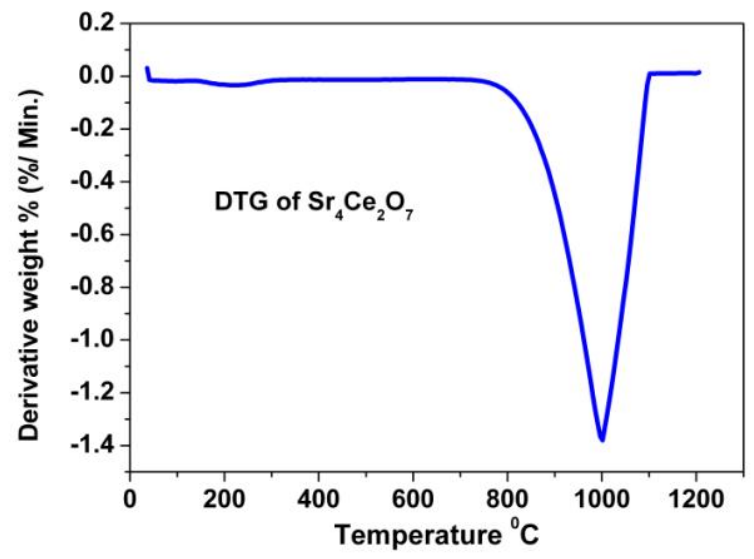

Fig. 2: DTG curve of $\mathrm{Sr}_{4} \mathrm{Ce}_{2} \mathrm{O}_{7}$

The curve DTG shown in Fig. 2 the sharp endothermic peak at $980{ }^{\circ} \mathrm{C}$ is attributed due to the loss of $\mathrm{CO}_{2}$. This endothermic peak observed in the DTG curve indicates that the starts at $965^{\circ} \mathrm{C}$ and inflection occurs at $1061{ }^{\circ} \mathrm{C}$. The peak observed in the DTG curve corresponding to the weight loss in the TG curve. Beyond the temperature $1100{ }^{\circ} \mathrm{C}$, the reaction proceed and finally a stable residue $\mathrm{Sr}_{4} \mathrm{Ce}_{2} \mathrm{O}_{7}$. No further loss is found, suggesting that the $\mathrm{Sr}_{4} \mathrm{Ce}_{2} \mathrm{O}_{7}$ can be prepared at higher than $1100^{\circ} \mathrm{C}$. Following chemical reaction is expected to occur during the decomposition stage,

\subsection{X-ray diffraction}

Several samples of $\mathrm{Sr}_{4} \mathrm{Ce}_{2} \mathrm{O}_{7}$ have been synthesized by solid state reaction method. Duplicate compositions have also been made to check on the consistency of behavior. We kept the muffle Furness temperature at $1200^{\circ} \mathrm{C}$ for $40-50$ hours then the structure and phase purity of the synthesized $\mathrm{Sr}_{4} \mathrm{Ce}_{2} \mathrm{O}_{7}$ phosphor was investigated by X-Ray Diffraction Method. Results are shown in Fig. 3. All diffraction patterns were obtained using Cu Ka radiation $\left(\lambda=1.54051 \mathrm{~A}^{\circ}\right)$, at $30 \mathrm{kV}$ and $15 \mathrm{~mA}$. Measurements were made from $2 \theta=10^{\circ}$ to $80^{\circ}$ with steps of $0.02^{\circ}$. The crystallite size of powders samples were calculated from X-ray peak broadening of the diffraction using Scherer's equation

$$
D=0.9 \lambda / \beta . \operatorname{Cos} \theta
$$

Where, $D$ is the crystallite size in $n m, \beta$ represents full width at half maximum (FWHM) of XRD lines, $\lambda$ is the radiation wavelength of $X$-ray $\left(\lambda=1.54051 \mathrm{~A}^{\circ}\right)$, and $\theta$ is diffraction peak angle.

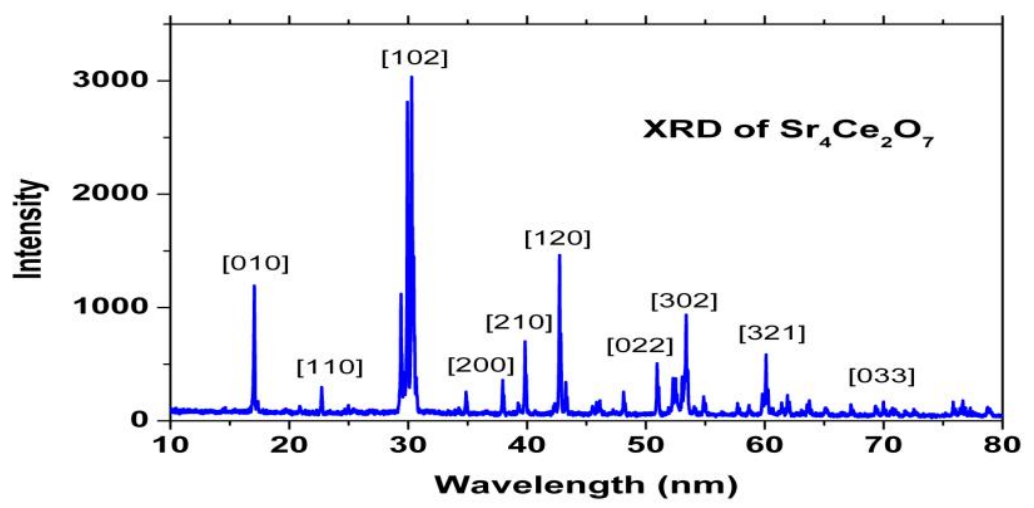

Fig. 3: XRD pattern of $\mathrm{Sr}_{4} \mathrm{Ce}_{2} \mathrm{O}_{7}$.

The calculated average crystallite size of the $\mathrm{Sr}_{4} \mathrm{Ce}_{2} \mathrm{O}_{7}$ phosphor is $49 \mathrm{~nm}$. The computer program POWD (an Interactive Powder Diffraction Data Interpretation and Indexing Program, Version 2.2) was used to calculate hkl and d values which are reported in table 1.The XRD patterns of the powders revealed that the structure of $\mathrm{Sr}_{4} \mathrm{Ce}_{2} \mathrm{O}_{7}$ is orthorhombic having lattice parameters $a=5.9431 \mathrm{~A}^{\circ}, b=5.1929 \mathrm{~A}^{\circ}, c=7.0644 \mathrm{~A}^{\circ}$ and cell volume $\mathrm{V}=218.02\left(\mathrm{~A}^{\circ}\right)^{3}$. JCPDS data card of $\mathrm{Sr}_{4} \mathrm{Ce}_{2} \mathrm{O}_{7}$ material is not available. 


\subsection{FT-IR Spectrometry}

The synthesized $\mathrm{Sr}_{4} \mathrm{Ce}_{2} \mathrm{O}_{7}$ by solid state reaction method have been subjected to Fourier transform infrared studies, which are used to analyze qualitatively the presence of functional group in the powder. The FTIR spectrums of powders were recorded using IR affinity-1 made by Shimadzu FTIR Spectrometer by $\mathrm{KBr}$ pellet technique. The FTIR spectrum of the $\mathrm{Sr}_{4} \mathrm{Ce}_{2} \mathrm{O}_{7}$ is shown in Fig. 4. The peaks at $3700 \mathrm{~cm}^{-1}$ are assigned to water molecules that may be present due to absorption of moisture. 3450 and $1110 \mathrm{~cm}^{-1}$ is assigned to the hydrogen bonding in water and impurities, usually present in $\mathrm{KBr}$ respectively. The absorption peaks at 1770, 1450,1022, 856, 705 and $699 \mathrm{~cm}^{-1}$ were assigned to stretching characteristics of $\mathrm{SrCO}_{3}[4]$. The absorption peak between $600-300 \mathrm{~cm}^{-1}$ is assigned to the metal oxide frequency band.

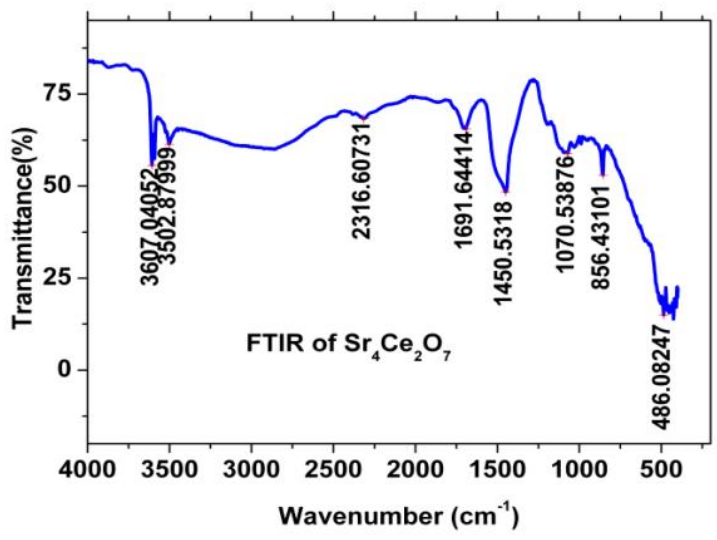

\subsection{Raman spectrometry}

Fig. 4: FTIR spectrum of $\mathrm{Sr}_{4} \mathrm{Ce}_{2} \mathrm{O}_{7}$

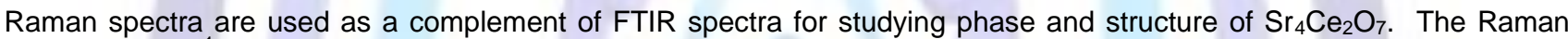
shift at $704 \mathrm{~cm}^{-1}$ is assigned to symmetric stretching mode of $\mathrm{SrCO}_{3}$ which coincide well with the IR features. The shift at $553 \mathrm{~cm}^{-1}$ is attributed to antisymmetric bending vibration. Two strong Raman shift at 286 and $387 \mathrm{~cm}^{-1}$ are detected, which can be attributed to the stretching modes of the $\mathrm{Ce}-\mathrm{O}_{2}$ and $\mathrm{Ce}-\mathrm{O}_{1}$ of $\mathrm{CeO}_{6}$ octahedra in $\mathrm{Sr}_{4} \mathrm{Ce}_{2} \mathrm{O}_{7}$ respectively. So the contribution of $\mathrm{Ce}-\mathrm{O}_{2}$ bonds increases corresponding with $\mathrm{Ce}-\mathrm{O}_{1}$ bonds to induce the charge transfer [4], which related to the luminescence of this material.

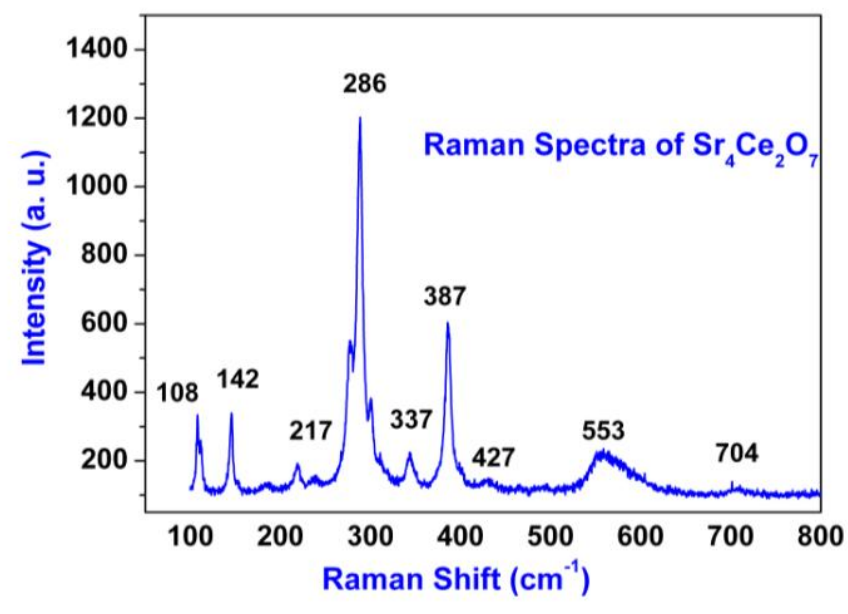

Fig. 5: Raman spectrum of $\mathrm{Sr}_{4} \mathrm{Ce}_{2} \mathrm{O}_{7}$.

\subsection{Luminescent properties}

Fig. 5 shows the excitation spectra of $\mathrm{Sr}_{4} \mathrm{Ce}_{2} \mathrm{O}_{7}$ blue phosphor. The excitation spectra consist of two bands observed at low and high wavelength; respectively. The luminescence of $\mathrm{Sr}_{4} \mathrm{Ce}_{2} \mathrm{O}_{7}$ is thought to originate from a legend-to-metal charge transfer. The emission spectrum excited by $320 \mathrm{~nm}$ as shown in fig. 6 . The spectrum shows broad band in the region $300-700 \mathrm{~nm}$ with a peak around $474 \mathrm{~nm}$. The emission band can be assigned to transitions of $\mathrm{Ce}^{3+}$ ions. 


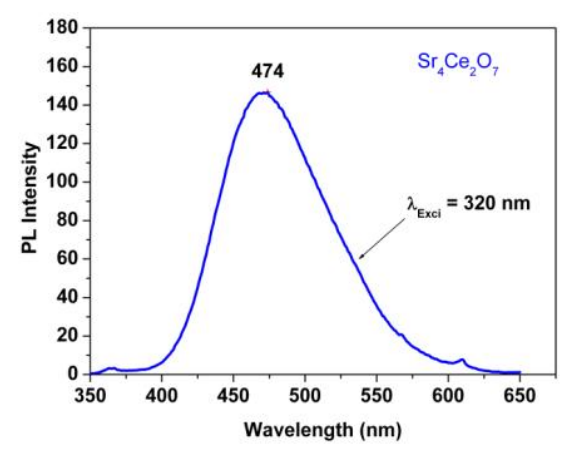

Fig.6: Excitation spectrum of $\mathrm{Sr}_{4} \mathrm{Ce}_{2} \mathrm{O}_{7}$

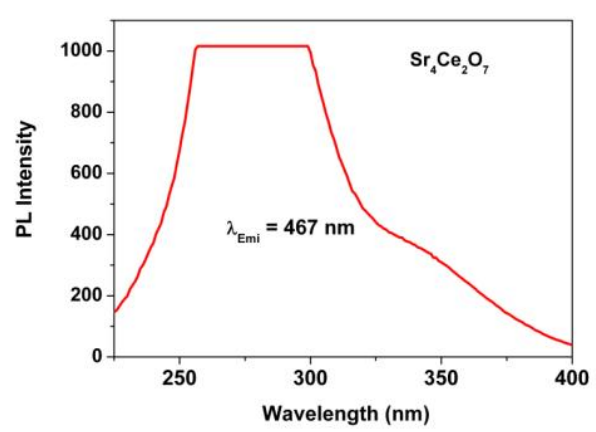

Fig. 7: Emission spectrum of $\mathrm{Sr}_{4} \mathrm{Ce}_{2} \mathrm{O}_{7}$

\section{CONCLUSIONS}

- A new Strontium Cerium Oxide $\mathrm{Sr}_{4} \mathrm{Ce}_{2} \mathrm{O}_{7}$ was successfully synthesized by solid state reaction method.

- The XRD patterns of the powders revealed that the structure of $\mathrm{Sr}_{4} \mathrm{Ce}_{2} \mathrm{O}_{7}$ is Orthorhombic,

- The emission spectra of $\mathrm{Sr}_{4} \mathrm{Ce}_{2} \mathrm{O}_{7}$ phosphor was observed under excitation $320 \mathrm{~nm}$, phosphor shows broad emission from $350-650$ peaking at $474 \mathrm{~nm}$.

- The as synthesized $\mathrm{Sr}_{4} \mathrm{Ce}_{2} \mathrm{O}_{7}$ phosphor with strong blue- white emitting could be a good candidate for advanced display devices.

\section{ACKNOWLEDGMENTS}

The author expresses their sincere thanks to Dr. K. V. R. Murthy, M. S. University Baroda. We are also thankful to Dr. N. O. Girase, the Principal, and Dr. K.D. Girase Vice principal, S. V. S's Dadasaheb Rawal College, Dondaicha for continuous encouragement.

\section{REFERENCES}

[1] Danielson E, Devenney M, Giaquinta D M, Golden J H, Haushalter, R C, McFarland E W, Poojary D M, Reaves C M Weinberg, A rare earth phosphor containing one-dimensional chains identified through combinatorial methods. 1998; Science, 279: 837-839.

[2] Fu Shi-Liu, Yin Tao, and Chai Fei, Synthesis and characterization of $\mathrm{Ca}_{2} \mathrm{Sn}_{1-\mathrm{x}} \mathrm{Ce}_{\mathrm{x}} \mathrm{O}_{4}$ with blue luminescence originating from $\mathrm{Ce}^{4+}$ charge transfer transition, 2007 Chinese Physics,;16(10): 3129-3133.

[3] Xiuzhen Xiao, Bing Yan. $\mathrm{Sr}_{2} \mathrm{CeO}_{4}: \mathrm{Eu}^{3+}$ and $\mathrm{Sr}_{2} \mathrm{CeO}_{4}: 5 \mathrm{~mol} \% \mathrm{Eu}^{3+}, 3 \mathrm{~mol} \% \mathrm{Dy}^{3+}$ microphosphors: Wet chemistry synthesis from hybrid precursor and photoluminescence properties. $2008 \mathrm{~J}$. of Phy. and Chem. of Solid,;69:1665-1668.

[4] Chunxiang Zhang, Wenjun Jiang, Xujie Yang, Qiaofeng Han, Qingli Hao, Xin Wang. Syntheis and luminescent property of $\mathrm{Sr}_{2} \mathrm{CeO}_{4}$ phosphor via EDTA-complexing process, 2009; J. of Alloys and Compounds, 474: 287-291.

[5] Yong Dong Jiang, Fuli Zhang and Christopher J. Summers, and Zhong Lin Wang. Synthesis and properties of $\mathrm{Sr}_{2} \mathrm{CeO}_{4}$ blue phosphor for field emission displays, 1997; Applied Physics Letters, 74:1677-1679.

[6] Rahul Ghildiyal, Pallavi Page, and Murthy KVR. Photoluminescence and thermoluminescence properties of $\mathrm{Sr}_{3} \mathrm{Al}_{2} \mathrm{O}_{6}: \mathrm{Tb}^{3+} 2008$ Mat. Research Bulletin.; 43:353-360.

[7] Niyaz Pravin Shaik, N V Poornachandra Rao, B. Subbarao, Murthy K V R, Photoluminescence study on $\mathrm{Sr}_{2} \mathrm{CeO}_{4}$ Nanophosphor, . 2011; World J. of Chemistry6(2):115-117.

[8] Qiao Yanmin, Zhang Xinbo, Ye Xiao, Chen Yan, Guo Hai. Photoluminescent properties of $\mathrm{Sr}_{2} \mathrm{SiO}_{4}$ : $\mathrm{Eu}^{3+}$ and $\mathrm{Sr}_{2} \mathrm{SiO}_{4}: \mathrm{Eu}^{2+}$ Phosphors prepared by solid state reaction method, 2009; Journal of Rare Earths, 27(2) : 223226.

[9] Sue Jin Kim, Hyung II Won' Nersisyan Hayk, Chang Whan Won , Duk Young Jeon , and Artavazd G. Kirakosyan, Preparation and characterization of $\mathrm{Sr}_{4} \mathrm{Al}_{2} \mathrm{O}_{7}$ : $\mathrm{Eu}^{3+}, \mathrm{Eu}^{2+}$ phosphors, 2011; Material Science and Engineering B, 176(18):1521-1525.

[10] Haiyan JIAO, Yuhuab WANG, Jiachi Zhang, Novel red phosphors for light emitting diodes: $\mathrm{Sr}_{2-y} \mathrm{Ce}_{1-x} \mathrm{Ti}_{x} \mathrm{O}_{4}$ : $\mathrm{yEu}^{3+}, 2009$ Journal of Physics : Conference Series 152, 012089.

[11] Zhang Chunxiang, Shi Jianshe, Yang Xujie, Lu Lude and Wang Xin, Preparation, characterization and luminescence of $\mathrm{Sm}^{3+}$ or $\mathrm{Eu}^{3+}$ doped $\mathrm{Sr}_{2} \mathrm{CeO}_{4}$ by a modified sol- gel method, 2010, J. of Rare earths, 28: 513518. 


\section{Author' biography with Photo}
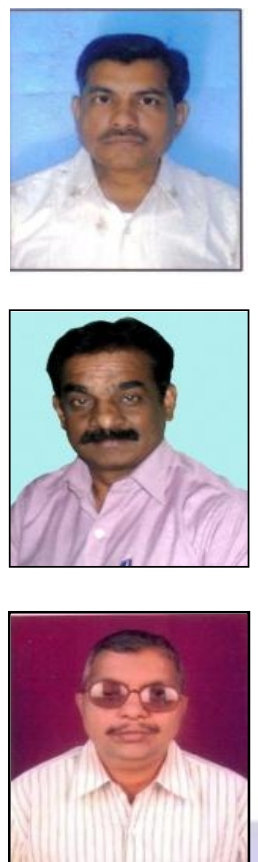

1) Pradip Z. Zambare obtained M.Sc. degree in Physics from M. S. University, Baroda, India in 1988. He is presently working as Associate professor in Department of Physics, S.V.S's Dadasaheb Rawal, College, Dondaicha, India. He worked on rare earth ions doped inorganic phosphor materials. His current research interest is in the synthesis and characterization of blue emitting phosphor for solid state lighting. He has published many research papers in various journals. He is a life member of Luminescence Society of India [LSI].

2) K. D. Girase obtained M.Sc. degree in Physics from University of Poona, India in 1988. He obtained Ph.D. degree in Physics from North Maharashtra University, Jalgaon India. He is presently working as vice Principal and associate professor in S.V.S's Dadasaheb Rawal, College, Dondaicha, India. He worked on crystal growth, thin film and rare earth ions doped inorganic phosphor materials for lamp industry. He has published many research papers in various journals. He is a life member of Luminescence Society of India [LSI].

3) O. H. Mahajan obtained M. Sc. Degree and Ph.D. degree in Applied Physics from Faculty of Technology and Engineering, MS University of Baroda, Vaodara. He is presently working as Head, and Associate Professor in Physics Department, M.J. College Jalgaon, India. During his research carrier, he is involved in the Luminescence (For Lamps and Sources; Specific area of expertise: Lamp Phosphors Thermo luminescence). He has published many research papers in various journals. He is a Fellow of Luminescence

Society of India.

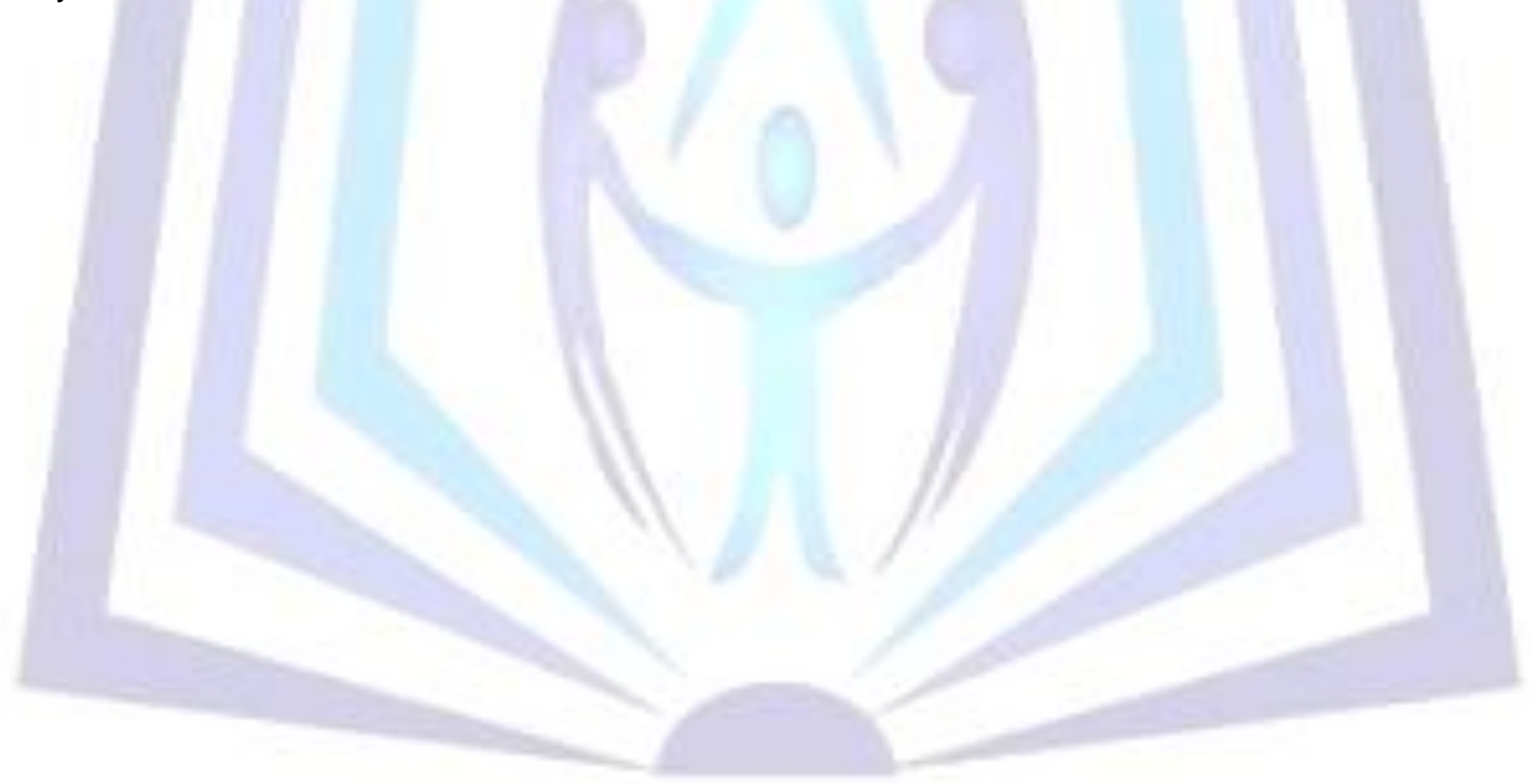

